\title{
VALIDITAS LKPD BERBASIS PERMAINAN TRADISIONAL CONGKLAK MATERI KPK DAN FPB PADA SISWA KELAS IV SD NEGERI 99 KOTA BENGKULU
}

\author{
${ }^{1}$ Tamara Fitriani, ${ }^{2}$ Rusdi, ${ }^{3}$ Ringki Agustinsa \\ Program Studi Pendidikan Matematika FKIP Universitas Bengkulu

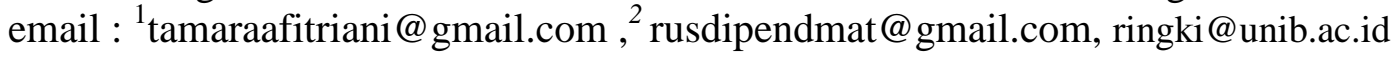

\begin{abstract}
Abstrak
Penelitian ini bertujuan untuk menghasilkan Lembar Peserta Didik Berbasis Permainan Tradisional Congklak Materi KPK dan FPB Pada Siswa Kelas IV SD Negeri 99 Kota Bengkulu yang memenuhi kategori valid, praktis, dan efektif. Penelitian ini merupakan penelitian pengembangan (Research and Development) dengan modifikasi model 4D Thiagarajan menjadi 3 tahap yaitu tahap pendefinisian (define), tahap perancangan (design), tahap pengembangan (develop) yang terdiri dari validitas, kepraktisan, dan efektifitas. Hasil penelitian menunjukkan bahwa Lembar Kerja Peserta Didik Berbasis Permainan Tradisional Congklak Materi KPK dan FPB Pada Siswa Kelas IV SD Negeri 99 Kota Bengkulu termasuk dalam kategori: (a) valid dari aspek materi, kontruksi, dan bahasa dengan skor rata-rata 4,69; (b) sangat praktis dengan skor rata-rata 4,48; dan (c) efektifitas berdasarkan: 1) aktivitas peserta didik dengan skor rata-rata 4,41 dalam kategori sangat baik; 2) aktivitas pendidik dengan skor rata-rata 4,55 dalam kategori sangat baik; 3) respon peserta didik dengan skor rata-rata 4,49 dalam kategori sangat baik; 5) hasil belajar peserta didik mencapai ketuntasan klasikal.
\end{abstract}

Kata Kunci : Validitas, Kata Kunci : Lembar Kerja Peserta Didik, Permainan Tradisional Congklak.

\begin{abstract}
This Research was to Produce the Students' Worksheet based on Congklak Traditional Game with Materials Lowest Common Multiple and Highest Common Factor at Fourth Grade Students SD Negeri 99 Bengkulu City that filled categorries valid, practical, an effective. The research was research and development with modification 4D Thiagarajan became three stages were defining stage, desiging stage, and developing stage that consited of validity, practicality, and effectiveness. and effectiveness test. The result of research showed that students' worksheet based on traditional game congklak with material KPK and FPB at fourth grade students SD Negeri 99 Bengkulu City included incategories: a) valid from aspects of material, construction, and language with average score 4,69. $b$ ) very practical with average score 4,48. c) the effectiveness based on: 1) the students' activities are with avarage score 4,41 in very good category 2) the teachers' activities are with avarage score 4,55 in very good category 3) the students'responses are with avaragescore 4,49 in very good category 5) the sudy result of students reached classical thoroughness.
\end{abstract}

Keywords : Validity, The Student's Worksheets, Congklak Traditional Game

\section{PENDAHULUAN}

Matematika merupakan mata pelajaran yang diajarkan mulai dari sekolah dasar sampai perguruan tinggi. Hal ini menunjukkan pentingnya peranan matematika dalam dunia pendidikan dan perkembangan teknologi.
Matematika merupakan cabang ilmu pengetahuan yang banyak digunakan di berbagai cabang ilmu pengetahuan lainnya. Permen No. 22 Tahun 2006, mata pelajaran matematika perlu diberikan kepada semua peserta didik mulai dari sekolah dasar hingga 
ke perguruan tinggi untuk membekali peserta didik dengan kemampuan berpikir logis, analisis, sistematis, kritis, dan kreatif, serta kemampuan bekerjasama. Matematika merupakan salah satu ilmu yang perlu diajarkan karena selalu digunakan dalam segi kehidupan dan dapat meningkatkan kemampuan berpikir logis serta sistematis.

Pembelajaran matematika tidak hanya menekankan konsep, tetapi juga menyiapkan peserta didik yang cakap berpikir dalam pemecahan masalah. Pembelajaran matematika juga dapat digambarkan sebagai proses komunikasi antar peserta didik dengan pendidik dan peserta didik dengan peserta didik untuk memperoleh pengetahuan dan keterampilan sistematis. Pengaplikasian ilmu matematika banyak terkait dengan masalah kehidupan sehari-hari, oleh karena itu peserta didik dituntut untuk memiliki kemampuan yang berkenaan dengan proses berpikir secara kritis yang penting untuk pengkajian masalah yang berkaitan dengan kehidupan sehari-hari. Berdasarkan uraian di atas dapat disimpulkan bahwa proses pembelajaran matematika hendaklah dikaitkan dengan kehidupan seharihari agar peserta didik mampu memahami konsep materi yang diberikan oleh pendidik.

Namun, berbeda halnya dengan hasil observasi awal yang dilakukan di SDN 99 Kota Bengkulu yang masih menunjukkan matematika sebagai mata pelajaran yang sulit dan membosankan bagi banyak peserta didik di sekolah tersebut. Hal ini dikarena matematika merupakan cabang ilmu yang mengandung banyak konsep abstrak sehingga peserta didik merasa sulit mempelajari matematika terutama peserta didik pada tingkat sekolah dasar. Kesulitan maupun kemampuan peserta didik dalam memahami materi pada kegiatan belajar mengajar tidak lepas dari proses komunikasi yang mengandung proses timbal balik antara peserta didik dengan pendidik. Kegiatan belajar mengajar akan berjalan secara efektif apabila terdapat unsur yang memotivasi peserta didik untuk belajar seperti pembelajaran menarik, peserta didik semangat belajar, tujuan pembelajaran jelas dan peserta didik dapat merasakan manfaat dari pembelajaran. Dari masalah yang ditemukan di sekolah, perlu adanya solusi untuk mengatasi permasalahan tersebut yakni dengan pengembangan bahan ajar dalam proses pembelajaran matematika. Salah satu bahan ajar yang dianggap mudah untuk dipahami oleh peserta didik tingkat sekolah dasar adalah LKPD. Dalam penelitian ini pengembangan LKPD yang berbasis permainan tradisional dianggap mampu untuk memecahkan permasalahan yang ada pada peserta didik di sekolah dasar. Pengembangan LKPD berbasis permainan tradisional ini dianggap sebagai media pembelajaran matematika yang dapat meningkatkan semangat, keaktifan peserta didik serta pemahaman konsep yang sesuai dengan kompetensi dasar.

Permainan yang dipilih adalah permainan tradisional dakon atau yang lebih sering dikenal dengan nama congklak yang dikembangkan menjadi permainan congklak matematika. Permainan ini dipilih karena memiliki unsur matematika pada permainannya. Kemudahan cara bermainan congklak menjadikan pertimbangan oleh peneliti untuk memilih permainan tersebut. Selain itu, permainan congklak yang sudah sangat jarang dimainkan oleh anak-anak bahkan banyak yang belum mengetahui bahwa terdapat unsur matematika di dalam permainan tradisional tersebut, ini juga menjadi alasan peneliti untuk memilih permainan tersebut.

Berdasarkan uraian latar belakang masalah di atas, maka peneliti tertarik untuk mengembangkan LKPD berbasis permainan tradisional pada pokok bahasan KPK dan FPB yaitu dengan penelitian yang berjudul "Pengembangan Lembar Kerja Peserta Didik Berbasis Permainan Tradisional Congklak Materi KPK dan FPB Pada Siswa Kelas IV SD Negeri 99 Kota Bengkulu". Permainan tradisional yang digunakan dalam penelitian dan pengembangan yang dilakukan adalah permainan congklak. Permainan congklak merupakan alat bermain yang sudah ada sejak 
zaman dahulu dan diwariskan secara turun menurun. Menurut Ismail dalam Hasanah dan Pratiwi (2015) Congklak adalah suatu permainan tradisional yang dilakukan oleh dua orang. Permainan ini menggunakan papan congklak dan 98 buah biji yang dinamakan biji congklak. Pada umumnya papan congklak terbuat dari kayu dan plastik, sedangkan bijinya terbuat dari cangkang kerang, biji-bijian, dan sintetik dari plastik yang menyerupai cangkang kerang. Papan congklak terdiri dari 16 lubang yang terdiri atas 14 lubang kecil dan 2 lubang besar di kedua sisinya.

Namun dalam penelitian ini, permainan congklak diubah menjadi permainan congklak matematika yakni papan congklak terbuat dari karton dan dibuat lingkaran sebanyak 32 yang terdiri dari 28 lingkaran kecil dan 4 lingkaran besar pada setiap sisi kiri dan kanan. Dengan memberi nomor pada setiap lingkaran kecil dari angka 1 hingga 28, dan terdiri dari dua orang pemain masing-masing memiliki 15 biji congklak. Tujuan dari penomoran adalah untuk memainkan congklak dengan menggunakan konsep matematika pada pokok bahasan KPK dan FPB. Jika biasanya bermain congklak dengan cara mengambil biji yang telah terisi di dalam lubang kecil pada papan congklak. Lain halnya dengan congklak matematika dalam penelitian ini biji terletak di lingkaran besar yang terdapat di kedua sisinya. Kemudian dimasukkan ke dalam lingkaran kecil sesuai dengan angka pada soal yang terdapat didalam LKPD yang telah diberikan pada setiap kelompok. Bagian dari papan congklak matematika terlihat pada gambar 2.1

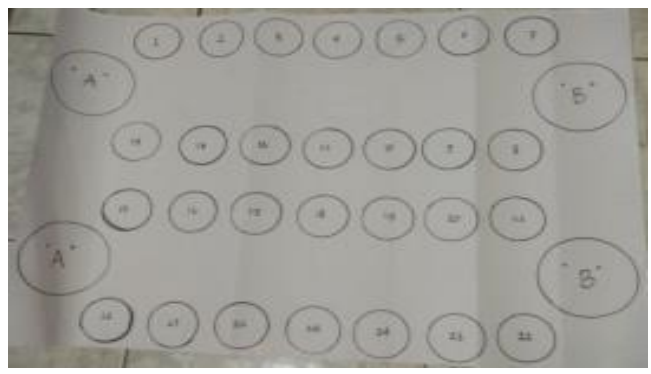

\section{Gambar 1 Papan Congklak Matematika Terbatas Hingga Angka 28}

Dari gambar 2.1 terdapat dua lingkaran besar yang berada di sisi kanan dan kiri, yang memiliki simbol A dan B. Simbol A dan B merupakan bilangan yang akan dijadikan bilangan KPK dan FPB dari kedua pemain. Sedangkan lingkaran kecil yang terdapat angka yang merupakan petunjuk untuk memasukkan biji congklak sesuai dengan bilangan yang dibutuhkan.

Dalam penelitian ini dibuat papan congklak matematika terbatas hingga angka 28 karena pada penelitian ini untuk menemukan KPK atau FPB. Sehingga untuk angka yang lebih dari 28 cukup dengan menggunakan konsep yang telah ditemukan pada penelitian yang menggunakan papan congklak matematika terbatas 28. Hal ini dikarenakan keterbatasan alat dan bahan untuk mempermudah dalam penelitian ini.

Aturan dalam permainan congklak matematika sebagai berikut:

a. Pemain mengundi antar kedua pemain sebelum memulai permainan

b. Pemain pertama bermain sesuai dengan bilangan yang ada pada lingkaran besar atau disebut dengan kerajaan masingmasing, dan dilanjutkan oleh pemain kedua.

c. Setelah bermain, kedua pemain mengamati papan congklak yang telah mereka masukkan biji congklak sesuai dengan bilangan pada masing-masing kerajaan.

d. Kedua pemain mengamati lingkaran kecil pada papan congklak yang telah dimasukkan biji congklak oleh keduanya.

e. Jika terdapat dua buah biji congklak pada satu lingkaran kecil pada papan congklak maka itu merupakan KPK atau FPB dari kedua bilangan yang tedapat pada kerajaan kedua pemain.

f. Kemudian kedua pemain menemukan KPK dan FPB dari kedua bilangan dan menyimpulkan dari permainan yang telah dilakukannya. 
Lembar kerja peserta didik adalah lembaran-lembaran yang berisi tugas yang harus dikerjakan oleh peserta didik. Lembar kegiatan biasanya berupa petunjuk atau langkah-langkah untuk menyelesaikan suatu tugas. Dan tugas tersebut haruslah jelas kompetensi dasar yang akan dicapai.

Prastowo (2015) lembar kerja peserta didik merupakan suatu bahan ajar cetak berupa lembar-lembar kertas yang berisi materi, ringkasan dan petunjuk-petunjuk pelaksanaan tugas pembelajaran yang harus dikerjakan oleh peserta didik, yang mengacu pada kompetensi dasar yang harus dicapai. Penulis berpendapat LKPD adalah bahan ajar yang berupa lembaran-lembaran yang memuat rangkaian materi, soal, dan petunjuk yang sistematis sehingga dapat menuntun peserta didik untuk memperoleh ilmu pengetahuan.

Dalam pengembangan LKPD pedidik harus lebih cermat serta memiliki keterampilan yang memadai. Karena sebuah lembar kerja harus memenuhi kriteria yang berkaitan dengan tercapai atau tidaknya sebuah kompetensi dasar yang harus dikuasai oleh peserta didik. Dari uraian di atas dapat disimpulkan bahwa LKPD merupakan lembar kegiatan peserta didik yang berisi tugas pembelajaran yang harus dikerjakan oleh peserta didik untuk mencapai tujuan dalam memenuhi kriteria dalam pembelajaran.

khususnya pada kelas rendah, memang memerlukan trik dalam pelaksanaa pembelajaran. Hai ini dikarenakan bahwa pada usia SD tersebut peserta didik masih diliputi sifat kekanak-kanakan atau masih suka bermaian. Dalam penelitain ini peneliti mengembangkan LKPD berbasis permainan tradisional congklak. Permaianan tradisional pada umumnya menggunkan model atau metode yang sesuai dengan permainan yang akan dilakukan, dalam penelitian ini permainan tradisional congklak dapat menggunakan metode pembelajaran ekspositori.

Langkah-langkah pembelajaran

ekspositori sebagai berikut:
1. Persiapan

Tahap persiapan ini merupakan tahap yang berkaitan dalam mempersiapkan peserta didik untuk menerima pelajaran. Langkah persiapan merupakan langkah yang sangat penting yang mana keberhasilan pembelajaran dengan menggunakan strategi pembelajaran dengan menggunakan pembelajaran ekspositori sangat tergantung pada langkah persiapan. Hal yang harus dilakukan dalam tahap persiapan antara lain :

a. Memberikan sugesti yang positif dan menghindari sugesti yang negatif.

b. Memulai dengan mengemukakan tujuan yang harus dicapai.

2. Penyajian

Langkah penyajian adalah langkah penyampaian materi pelajaran sesuai dengan yang telah dilakukan. Dalam tahap penyajian ini pendidik mengarahkan materi yang akan dipelajari dengan menggunakan LKPD berbasis permainan tradisional congklak agar peserta didik lebih mudah dalam menerapkannya pada proses pembelajaran.

3. Korelasi

Korelasi merupakan langkah menghubungkan materi pelajaran dengan pengalaman peserta didik atau dengan hal-hal lain yang memungkinkan peserta didik dapat memahami keterkaitannya dalam struktur pengetahuan yang telah dimilikinya (Hosnan, 2016: 376). Langkah korelasi dilakukan untuk memberikan makna terhadap materi pelajaran, baik makna untuk memperbaiki struktur pengetahuan yang telah dimilikinya maupun makna untuk meningkatkan kualitas kemampuan berpikir dan kemampuan motorik peserta didik. Dalam penelitian ini pada tahap kolerasi pendidik menjelaskan permainan tradisional congklak yang 
berkaitan dengan materi KPK dan FPB dala pengembangan LKPD.

4. Menyimpulkan

Tahap menyimpulkan merupakan tahap penting dalam memahami inti dari materi pembelajaran yang telah disajikan sebab melalui langkah menyimpulkan yang mana peserta didik dapat mengambil inti sari dari proses penyajian.

\section{Penerapan}

Penerapan merupakan langkah memperlihatkan kemampuan peserta didik setelah mereka menyimak penjelasan pendidik. Langkah penerapan ini berguna untuk pendidik dalam mengumpulkan informasi tentang penguasaan dan pemahaman materi pembelajaran oleh peserta didik. Teknik yang biasa dilakukan pada langkah ini di antaranya: (1) dengan membuat tugas yang relevan dengan materi yang telah disajikan, (2) dengan memberikan tes yang sesuai dengan materi pelajaran yang telah disajikan.

\section{METODE}

Jenis penelitian yang dipilih adalah penelitian dan pengembangan (research and development). Penelitian ini menggunakan model 4D Thiagrajan, Semmel dan Semmel yang dimodifikasi. LKPD yang dikembangkan adalah LKPD berbasis permainan tradisional congklak materi KPK dan FPB pada siswa kelas IV SD Negeri 99 Kota Bengkulu.

Tahap pengembangan model 4D Thiagarajan, Semmel, dan Semmel dalam Trianto (2011 : 93-96) disajikan sebagai berikut.

\section{Tahap Pendefinisian (Define)}

Tahap ini digunakan untuk menetapkan dan mendefinisikan kebutuhan-kebutuhan pembelajaran dengan menganalisis tujuan dan batasan materi. Tahap ini meliputi: 1) analisis awal akhir untuk menentukan masalah mendasar yang dihadapi dalam pembelajaran; 2) analisis peserta didik untuk menelaah peserta didik, dilakukan identifikasi terhadap karakteristik peserta didik yang sesuai dengan rancangan dan pengembangan pembelajaran; 3) analisis konsep untuk mengidentifikasi konsepkonsep utama yang akan diajarkan, menyusunnya secara sistematis, dan memilah konsep-konsep yang relevan; 4) analisis tugas untuk menentukan dan merinci isi materi ajar dalam bentuk garis besar; dan 5) spesifikasi tujuan pembelajaran untuk melakukan penjabaran indikator pencapaian hasil belajar tujuantujuan pembelajaran khusus.

2. Tahap Perancangan (Design)

Tahap ini digunakan untuk merancang perangkat pembelajaran yang meliputi: 1) penyusunan tes acuan patokan yang menjadi langkah awal untuk menghubungkan tahap pendefinisian dan perancangan; 2) pemilihan media yang tepat yaitu penyajian materi pelajaran; 3) pemilihan format yaitu mengkaji formatformat perangkat yang dikembangkan.

3. Tahap Pengembangan (Develop)

Tahap ini digunakan untuk menghasilkan perangkat pembelajaran yang telah direvisi atau diperbaiki berdasarkan masukan dari validator dan data yang diperoleh dari uji coba di lapangan. Perangkat yang dibuat harus melalui beberapa langkah berikut ini sebelum menjadi perangkat pembelajaran final : 1) validasi oleh para pakar untuk selanjutnya direvisi berdasarkan masukan para pakar; 2) simulasi yaitu kegiatan mengoperasikan rencana pembelajaran; 3) uji coba terbatas yang dilakukan terhadap peserta didik yang sesungguhnya; dan 4) perancangan awal perangkat pembelajaran yang melibatkan aktivitas peserta didik dan pendidik, perancangan awal perangkat pembelajaran dapat berupa Rencana Pelaksanaan Pembelajaran (RPP), LKPD, THB, buku guru, buku peserta didik, dan sumber belajar lain yang sesuai dengan kebutuhan. 
4. Tahap Penyebaran (Disseminate)

Perangkat pembelajaran yang telah memperoleh nilai positif dari para ahli dan melalui tes pengembangan perangkat pembelajaran tersebut kemudian dikemas, untuk disebarkan dan diterapkan dalam skala yang lebih luas.

Penulis menerapkan 3 tahapan untuk melakukan penelitian ini yaitu define (pendefinisian), design (perancangan) dan develop (pengembangan) uji validitas Prosedur penelitian pengembangan telah dimodifikasi disajikan sebagai berikut.

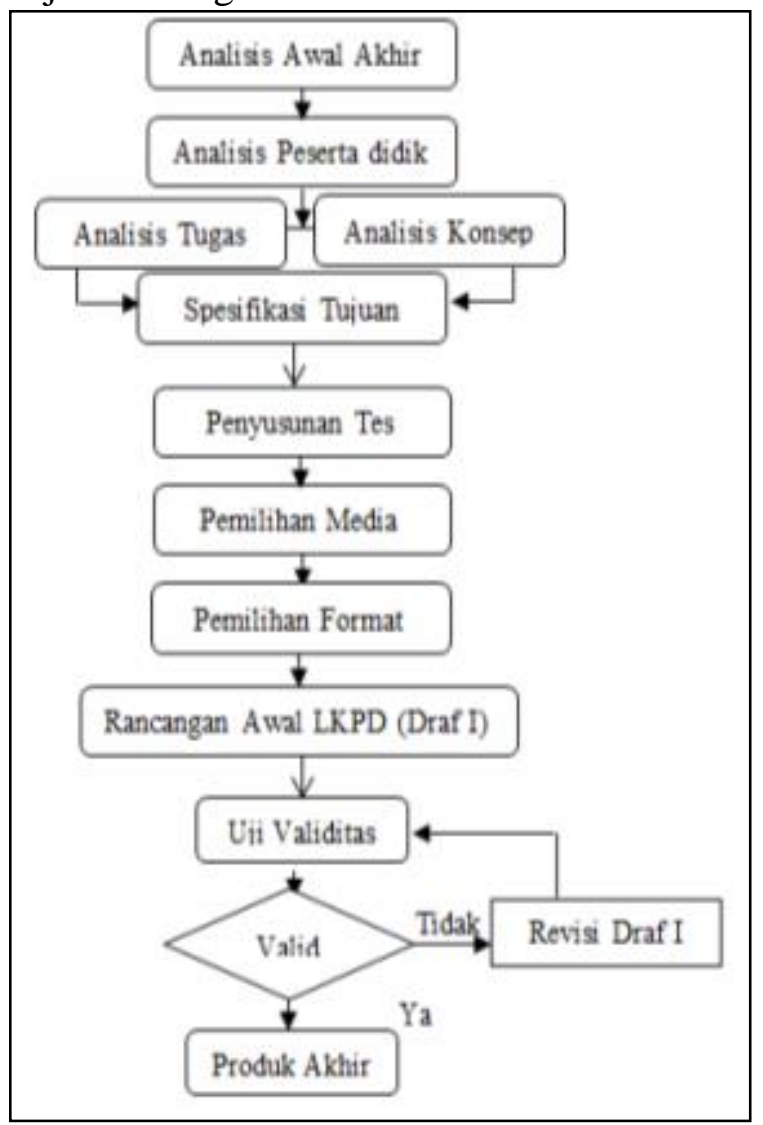

Gambar 2. Prosedur Penelitian

Instrumen yang digunakan pada penelitian ini berupa lembar validitas LKPD.

Lembar validitas LKPD dipergunakan untuk mengetahui valid atau tidaknya suatu LKPD yang dikembangakan berdasarkan pendapat validator. Lembar validitas yang digunakan dalam pengembangan LKPD ini merupakan gabungan dari validitas materi, konstruksi, dan bahasa.
Teknik analisis data yang digunakan pada penelitian yaitu analisis terhadap validitas LKPD. Analisis validitas dilakukan berdasarkan saran, tanggapan, dan penilaian dari validator. Langkah-langkah yang dilakukan untuk menganalisis validitas LKPD berbasis permainan tradisional congklak materi KPK dan FPB berikut :

1. Setiap butir pernyataan diberikan skor 1 sampai dengan 5, sehingga total skor minimal untuk 25 butir pernyataan lembar validitas adalah 25 dan total skor maksimalnya 25 x 5 yakni 75 .

2. Menghitung skor yang diberikan validator untuk lembar validasi materi, berikut rumusnya :

$$
\overline{V_{m}}=\frac{\sum_{i=1}^{n} v_{m i}}{n}
$$

Keterangan:

$\overline{V_{m}}:$ skor rata-rata validitas materi

$v_{m i}:$ skor rata-rata validior materi ke- $i$

$n$ : banyaknya validator materi

3. Menghitung skor yang diberikan validator untuk lembar validasi konstruksi, berikut rumusnya :

$$
\overline{V_{k}}=\frac{\sum_{i=1}^{n} v_{k i}}{n}
$$

Keterangan:

$\overline{V_{k}}:$ skor rata-rata validitas konstruksi

$v_{k i}$ : skor rata-rata validior konstruksi ke- $i$

$n$ : banyak validitor konstruksi

4. Menghitung skor yang diberikan validator untuk lembar validasi bahasa, berikut rumusnya :

$$
\overline{V_{b}}=\frac{\sum_{i=1}^{n} v_{b i}}{n}
$$
Keterangan:
$\overline{V_{b}}:$ skor rata-rata validitas bahasa
$v_{b i}:$ skor rata-rata validator bahasa ke- $i$
$n$ : banyaknya validitor bahasa 
5. Rata-rata skor validitas keseluruhan dihitung dengan rumus :

$$
\bar{V}=\frac{\overline{V_{m}}+\overline{V_{k}}+\overline{V_{b}}}{n}
$$

Keterangan :

$\bar{V}$ : skor rata-rata validitas

$\overline{V_{m}}$ : skor rata-rata validitas materi

$\overline{V_{k}}$ : skor rata-rata validitas konstruksi

$\overline{V_{b}}$ : skor rata-rata validitas bahasa

$n$ : banyaknya jenis lembar validitas

Kategori validitas keseluruhan LKPD sebagai berikut.

Tabel 1. Kategori Validitas LKPD

\begin{tabular}{|c|c|}
\hline $\begin{array}{c}\text { Skor Rata-Rata } \\
\text { Validitas }\end{array}$ & Kriteria \\
\hline$\overline{\mathrm{V}} \leq 1,8$ & Tidak Valid \\
\hline $1,8<\overline{\mathrm{V}} \leq 2,6$ & Kurang Valid \\
\hline $2,6<\overline{\mathrm{V}} \leq 3,4$ & Cukup Valid \\
\hline $3,4<\overline{\mathrm{V}} \leq 4,2$ & Valid \\
\hline $4,2<\overline{\mathrm{V}}$ & Sangat Valid \\
\hline
\end{tabular}

6. LKPD dinyatakan valid apabila hasil penilaian uji validitas mendapatkan kategori minimal valid dengan rata-rata skor yang diperoleh yaitu $3,4<\overline{\mathrm{V}} \leq 4,2$ dan LKPD perlu diperbaiki dan diuji validitas ulang jika rata-rata skor tersebut belum tercapai.

\section{HASIL DAN PEMBAHASAN}

Pengembangan LKPD berbasis permainan tradisional congklak materi KPK dan FPB pada siswa kelas IV SD Negeri 99 Kota Bengkulu . dan Kompetensi Dasar yang dipilih adalah 3.6 Menentukan Kelipatan Persekutuan Terkecil (KPK) dan Faktor Persekutuan Terbesar (FPB)

\section{Validitas LKPD}

LKPD yang telah dirancang dinyatakan valid oleh validator Bapak Edi Susanto, M.Pd dan guru matematika SDN 99 Kota Bengkulu yaitu Ibu Leli Nurhamilah, S.Pd. Hasil uji validitas LKPD digunakan untuk memperbaiki LKPD berdasarkan saran-saran dari validator. Penilaian validator mengenai LKPD 1 sampai LKPD 4 sebagai berikut.

Hasil penilaian kedua validator untuk LKPD 1, 2, 3, dan 4 memperoleh kategori sangat valid masing-masing menunjukkan skor rata-rata 4,69. Hal ini menunjukkan bahwa materi yang dimuat dalam keempat LKPD sudah sesuai dengan KD dan indikator yang telah ditetapkan kurikulum 2013, sesuai untuk membantu peserta didik dalam menemukan konsep, sesuai dengan kemampuan berpikir peserta didik tingkat SD sederajat. Keempat LKPD juga telah memenuhi syarat isi dan format yang telah ditentukan untuk mengembangkan LKPD. Bahasa yang digunakan telah memenuhi ketepatan bahasa untuk diterapkan dalam LKPD. Rata-rata skor validitas keseluruhan LKPD adalah 4,69, hal ini berarti secara keseluruhan LKPD dinyatakan sangat valid.

Menurut validator hal pertama yang perlu di perbaiki ialah letak cover yang memuat hingga 2 halaman. Hal ini membuat LKPD menjadi lebih banyak sehingga dapat membingungkan peserta didik untuk jenjang sekolah dasar. Berikut contoh cover yang memuat 2 halaman.
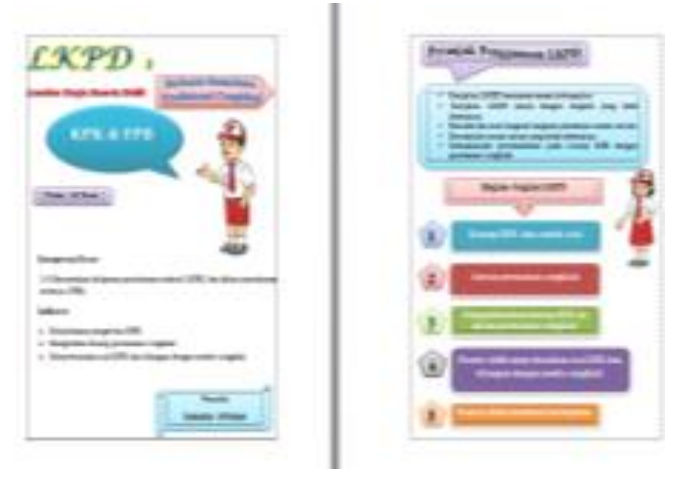

\section{Gambar 3. Cover Sebelum Revisi}

Menurut validator pada bagian cover ini sebaiknya digabukan saja menjadi satu halaman. Sehingga dapat memudahkan peserta didik melihat dan memahami isi dan tujuan dari LKPD yang dikembangkan. Berikut gambar bagian cover yang telah direvisi. 


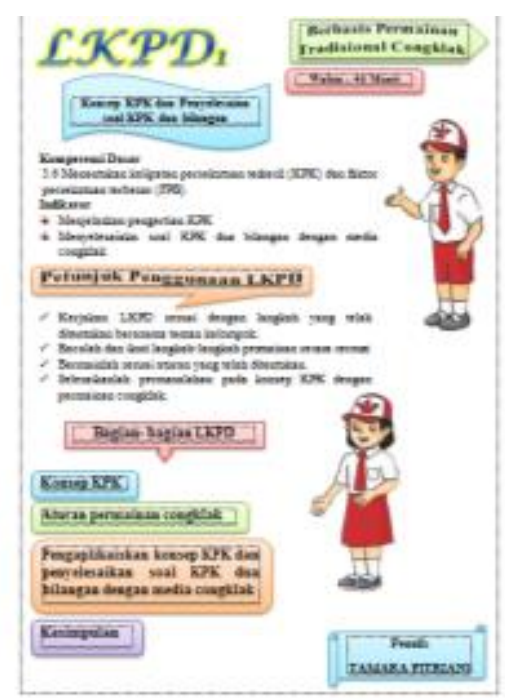

\section{Gambar 4. Cover Setelah Revisi}

Hal yang perlu diperbaiki selanjutnya yaitu warna pada gambar LKPD. Untuk penggunaan warna menurut saran dari validator harus menggunakan warna yang soft agar tulisan yang ada pada kolom yang berwarna ketika di fotocopy tampak dengan jelas. Berikut contoh warna pada kolom sebelum LKPD direvisiHal yang perlu diperbaiki selanjutnya yaitu warna pada gambar LKPD. Untuk penggunaan warna menurut saran dari validator harus menggunakan warna yang soft agar tulisan yang ada pada kolom yang berwarna ketika di fotocopy tampak dengan jelas. Berikut contoh warna pada kolom sebelum LKPD direvisi.

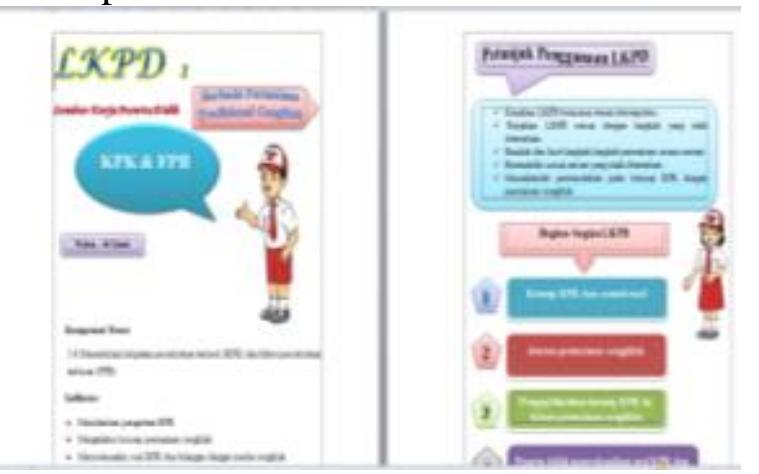

Gambar 5. Warna Pada Kolom Cover Sebelum Revisi

Hasil diskusi bersama validator agar LKPD dapat terlihat lebih jelas maka warna yang digunakan warna-warna soft. Berikut contoh gambar kolom pada LKPD yang telah di ganti warnanya.

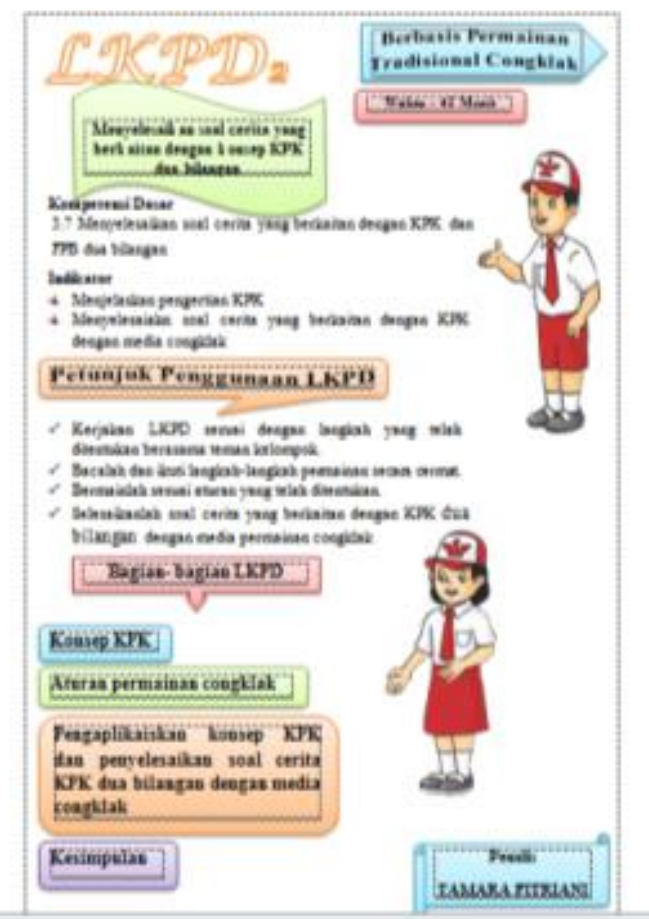

\section{Gambar 6. Warna Pada Kolom Cover Setelah Revisi}

Bagian yang direvisi selanjutnya pada bagian penyajian materi di dalam LKPD. Berdasarkan hasil diskusi dengan validator pada bagian ini sebaiknya dihilangkan. Berikut contoh LKPD sebelum direvisi.

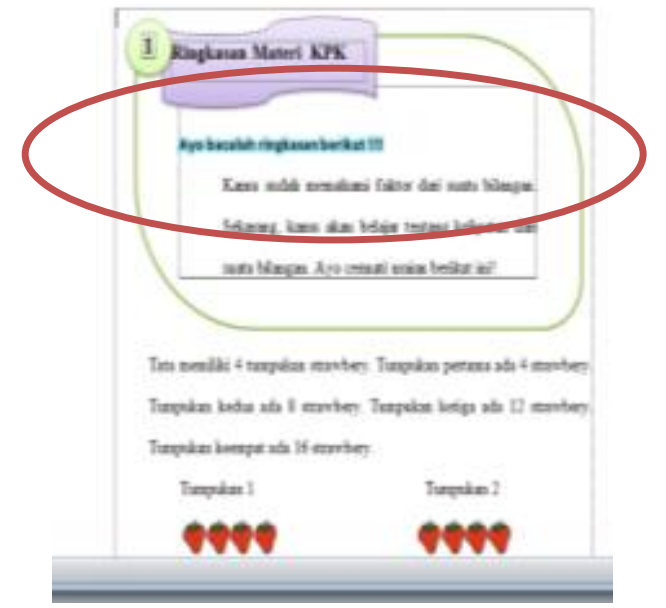

Gambar 7. Bagian Materi Sebelum Revisi

Setelah direvisi bagian tersebut menjadi seperti berikut. 


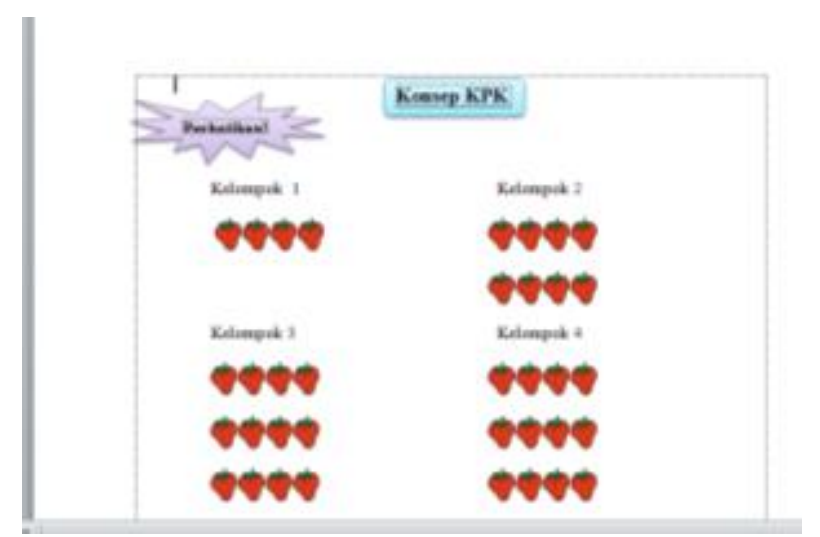

\section{Gambar 8. Bagian Materi Setelah Revisi}

Selanjutnya pada bagian aturan permainan congklak yang terpisah menjadi 2 halaman. Menurut validator bagian ini harus menjadi satu halaman agar mempermudah peserta didik dalam melihat aturan permainan congklak yang ada pada LKPD. Contoh bagian aturan permainan congklak sebelum direvisi sebagai berikut.

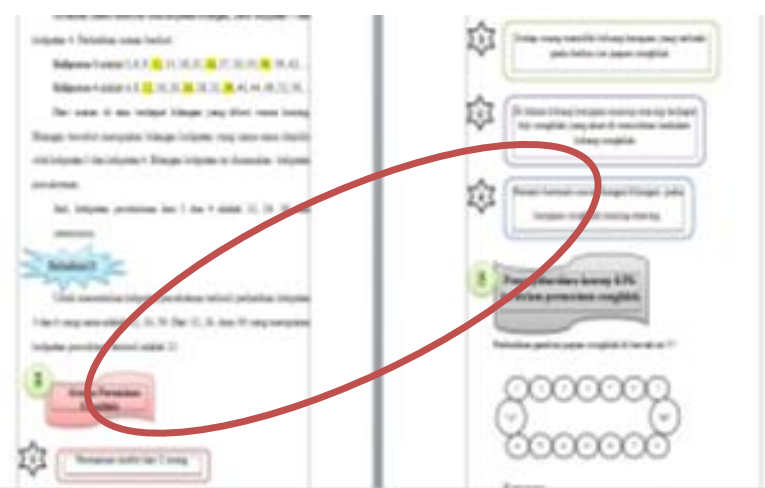

\section{Gambar 9. Bagian Aturan Permainan Congklak Sebelum Revisi}

Setelah revisi pada bagian aturan permainan tradisional congklak dijadikan satu halaman untuk memudahkan peserta didik pada saat pengaplikasian terhadap permainan tradisional congklak dalam menyelesaikan soal yang ada pada LKPD. Contoh bagian aturan permainan tradisional congklak setelah revisi sebagai berikut:

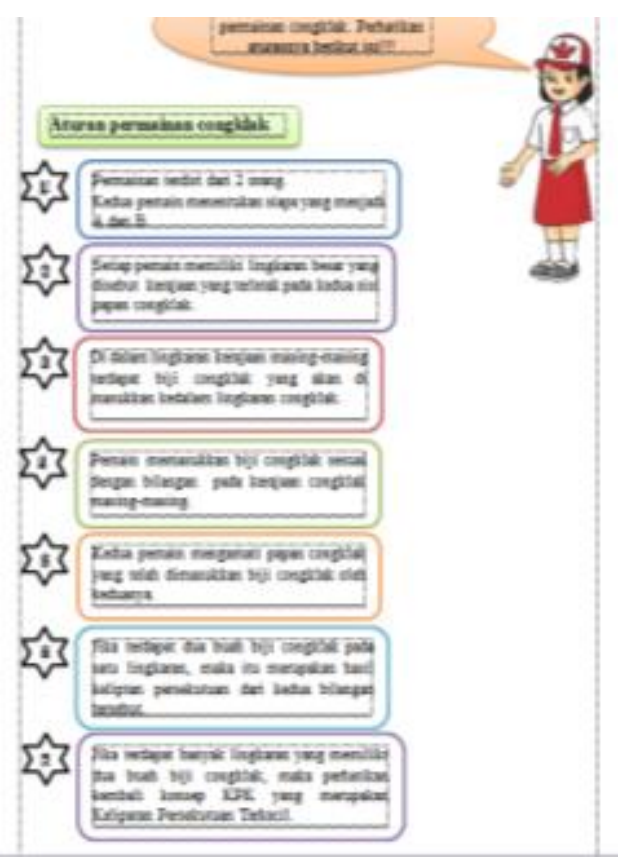

\section{Gambar 10. Bagian Aturan Permainan Congklak Setelah Revisi}

Hal yang harus direvisi terakhir adalah jumlah soal yang terlalu banyak. Berdasarkan hasil diskusi dengan validator untuk jenjang sekolah dasar soal di dalam LKPD tidak harus banyak yang terpenting ialah pemahaman konsep dapat dengan jelas pada setiap soal yang ada pada LKPD. Contoh soal sebelum direvisi sebagai berikut.
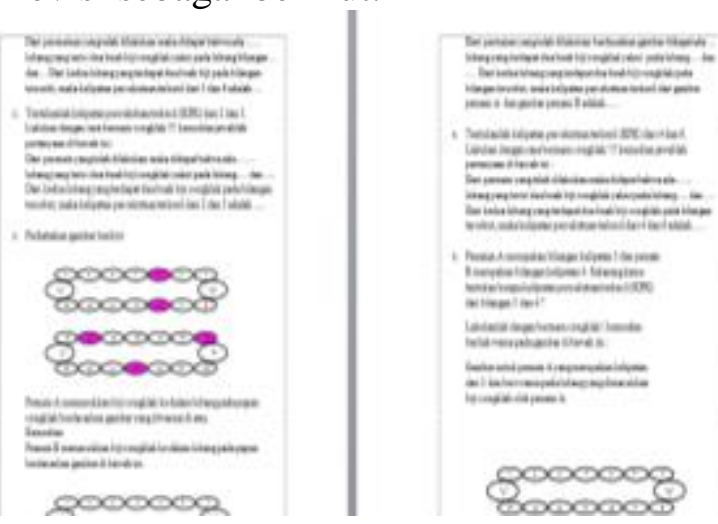

Gambar 12. Bagian Soal Sebelum Revisi Berdasarkan hasil diskusi dengan validator soal yang terdapat pada LKPD hanya sedikit namun tetap sesuai dengan indikator yang ingin dicapai. Contoh soal pada LKPD setelah revisi sebagai berikut: 


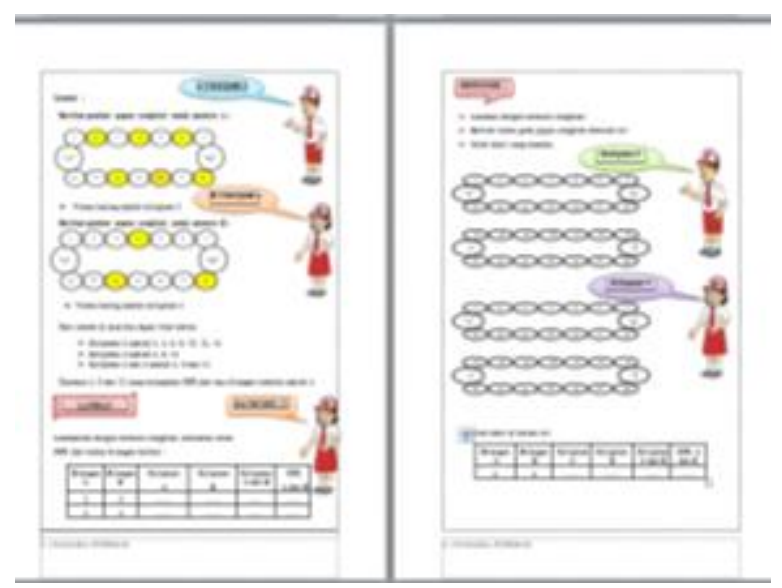

Gambar 12. Bagian Soal Setelah Revisi

Uji validitas terdiri dari tiga jenis yaitu uji validitas materi, konstruksi, dan bahasa yang dilakukan oleh 2 orang validator yaitu bapak Edi Susanto, S.Pd, M.Pd selaku dosen program studi Pendidikan Matematika Universitas Bengkulu dan ibu Leli Nurhamilah, S.Pd selaku pendidik matematika SD Negeri 99 Kota Bengkulu.

Rata-rata total validitas materi, konstruksi dan bahasa untuk seluruh LKPD adalah 4,69 dengan kriteria "sangat valid", namun validator menyarankan untuk dilakukan revisi pada materi, konstruksi dan bahasa agar LKPD menjadi lebih baik. Revisi banyak dilakukan pada aspek ketiganya yaitu materi yang disajikan sesuai dengan kemampuan berpikir peserta didik tingkat SD. Hasil validitas konstruksi berada dalam kriteria "sangat valid". Revisi yang dilakukan berkaitan dengan aspek kedua yaitu halaman tidak terlalu padat dengan tulisan, warna yang memuat di dalam LKPD, dan jangan terlalu banyak gambar. Validitas bahasa berada dalam kriteria "sangat valid". Revisi dilakukan pada aspek ketiga yaitu kesesuaian penggunaan bahasa pada LKPD dengan tingkat kedewasaan anak di jenjang $\mathrm{SD}$.

\section{PENUTUP}

\section{Simpulan}

Berdasarkan hasil penelitian pengembangan lembar kerja peserta didik (LKPD) berbasis permainan tradisional congklak materi KPK dan FPB pada siswa kelas IV SD Negeri 99 Kota Bengkulu diperoleh kesimpulan sebagai berikut :

1. Lembar Kerja Peserta Didik (LKPD) berbasis permainan tradisional congklak materi KPK dan FPB pada siswa kelas IV SD Negeri 99 Kota Bengkulu termasuk dalam kriteria sangat valid dengan skor rata-rata 4,69 pada aspek materi, konstruksi dan bahasa termasuk ke dalam kategori sangat valid.

2. Lembar Kerja Peserta Didik (LKPD) berbasis permainan tradisional congklak materi KPK dan FPB pada siswa kelas IV SD Negeri 99 Kota Bengkulu termasuk dalam kriteria sangat praktis dengan skor rata-rata 4,48 karena LKPD yang digunakan dengan baik oleh peserta didik untuk pembelajaran KPK dan FPB sesuai kurikulum 2013.

3. Lembar Kerja Peserta Didik (LKPD) berbasis permainan tradisional congklak materi KPK dan FPB pada siswa kelas IV SD Negeri 99 Kota Bengkulu termasuk kriteria sangat efektif dengan persentase $85,29 \%$ peserta didik yang dinyatakan tuntas karena :

a. LKPD telah disusun berdasarkan syarat-syarat penyusunan LKPD sehingga LKPD dapat membantu peserta didik mencapai tujuan pembelajaran.

b. LKPD sudah membuat peserta didik melaksanakan proses pembelajaran sesuai dengan langkah-langkah permaianan tradisional congklak sehingga peserta didik memperoleh hasil belajar yang tinggi.

\section{Saran}

Berdasarkan hasil penelitian pengembangan lembar kerja peserta didik (LKPD) berbasis permainan tradisional congklak materi KPK dan FPB pada siswa kelas IV SD Negeri 99 Kota Bengkulu disarankan berikut :

a. Kegiatan peserta didik pada saat mengerjakan LKPD dengan bimbingan 
dari pendidik. Karena untuk kegiatan pemebelajaran telah diberikan alokasi waktu saat mengerjakan LKPD jadi pendidik disini mengkondisikan jika terdapat banyak peserta didik yang bertanya sehingga membutuhkan bimbingan. Masalah ini dapat diatasi dengan menampung beberapa pertanyaan dan yang sama bisa disampaikan secara keseluruhan didepan kelas.

b. LKPD yang dikembangkan sebaiknya memberikan kesan menarik seperti gambar-gambar yang berkaitan dengan materi sehingga membuat peserta didik penasaran dan tertarik untuk membacanya.

\section{DAFTAR PUSTAKA}

Amrita, Kabut. 2009. Pengembangan Media Permainan Congklak Matematika Untuk Mengefektifakan Penyampaian Materi KPK dan FPB Kelas IV Di Sekolah Dasar. Jurnal Matematika FKIP Universitas Purwokerto.

Arikunto, S. 1989. Dasar-Dasar Evaluasi Pendidikan. Jakarta: Bina Aksara.

Dimyati, \& Mudjiono. (2013). Belajar dan Pembelajaran. Jakarta: Rineka Cipta.

Hamzah, A., \& Muhlisrarini. (2014). Perencanaan dan Strategi Pembelajaran Matematika. Jakarta: Rajawali Pers.

Hasanah, N., \& Pratiwi. (2015). Pengembangan Anak Melalui Permainan Tradisional. Banjarmasin : CV. Aswaja Pressindo

Hidayat, Asep. 2016. Pengaruh Penggunaan Alat Peraga Dakon Matematika Terhadap Hasil Belajar Matematika Siswa. Jurnal Universitas Negeri Syarif Hidayahtullah.

Maizora. Syafdi. 2011. "Pengembangan Web Pembelajaran Kalkulus Diferensial FKIP Universitas Bengkulu". Tesis tidak diterbitkan. Padang: Program Pasca Sarjana Universitas Negeri Padang.
Nurdin, S., \& Adriantoni. (2016). Kurikulum dan Pembelajaran. Jakarta: Rajawali Pers.

Permendikbud No. 21 Tahun 2016 tentang Standar Isi Pendidikan Dasar Dan Menengah. Jakarta : Kemendikbud.

Prastowo, A. (2015). Panduan Kreatif Membuat Bahan AjarInovatif. Yogyakarta: Diva Press.

Prastowo, A. 2013. Pengembangan Bahan Ajar Tematik. Jogjakarta: DIVA Press.

Sanjaya, Wina.2013. Penelitian Pendidikan. Jakarta: Prenada Media Group.

Septy, Liana, dkk. 2015. "Pengembangan Media Pembelajaran Komik Pada Materi Peluang di Kelas VIII”. Jurnal Didaktit Matematika Vol.2.No.2

ISSN: 2355-4185. Hal 16-26.

Sudjana. (1975). Metoda Statistika. Bandung: Tarsito.

Sugiyono. (2016). Metode Penelitian dan Pengembangan. Bandung: Alfabeta.

Trianto. (2012). Model Pembelajaran Terpadu. Jakarta: Bumi Aksara.

Widoyoko, E. P. (2009). Evaluasi Program Pembelajaran. Yogyakarta: Pustaka Pelajar.

Thiagarajan, Sivasailam, Dorothy S

Semmel, Melvyn I Semmel. 1974.

Instructional Development For Training Teachers of Exceptional

Children. Indiana: Indiana University 